\title{
Research on the Ownership Structure Optimization and Corporate Governance Improvement of China's Large State-Owned Shipping Company after Integration
}

\author{
Bing Liao, Siqin $\mathbf{Y u}^{*}$ \\ Shanghai Maritime University, Shanghai, China \\ Email: *excellentrabit@hotmail.com
}

How to cite this paper: Liao, B. and $\mathrm{Yu}$, S.Q. (2019) Research on the Ownership Structure Optimization and Corporate Governance Improvement of China's Large State-Owned Shipping Company after Integration. American Journal of Industrial and Business Management, 9, 1983-1884.

https://doi.org/10.4236/ajibm.2019.911130

Received: September 5, 2019

Accepted: November 19, 2019

Published: November 22, 2019

Copyright $\odot 2019$ by author(s) and Scientific Research Publishing Inc. This work is licensed under the Creative Commons Attribution International License (CC BY 4.0).

http://creativecommons.org/licenses/by/4.0/

\begin{abstract}
In the international shipping business industry, the degree of industry concentration is more and more intensive. Pushing native shipping industrial integration is an important route to possess the advantages of the scale economy, and foster the leading enterprises. The study on the ownership structure and corporate governance of Japan shipping companies enlightens China's large state-owned shipping company after integration.
\end{abstract}

\section{Keywords}

Traffic Transportation Economics, Equity Ownership Structure, Corporate Governance, Shipping Company, Integration

\section{Introduction}

At present, the Chinese government is making every effort to promote the strategic integration and reorganization of large state-owned enterprises, concentrate on building world-class enterprises with international competitiveness and specialization, enhance the competitiveness of Chinese enterprises to participate in global markets, and promote the improvement of business models and business operations of state-owned enterprises to improve efficiency and enhance the discourse power in relevant fields around the world.

Based on the ownership structure and corporate governance, this paper studies and analyzes the shareholding structure, corporate governance, industrial cooperation and business model of the world's leading integrated shipping enterprise groups. Combining with the development of China's shipping industry, propose 
suggestions for the improvement of equity structure, corporate governance and business models of China's large state-owned shipping companies after the integrations.

\section{Equity Structure and Corporate Governance}

\subsection{Equity Ownership Structure}

The shareholding structure refers to the proportion of shares of different natures in the company's total share capital and their mutual relationship. It usually refers to the concentration of shares and the composition of equity which can be highly concentrated, relatively controlled or highly dispersed. If the controlling shareholder holds more than $50 \%$ of the shares, it is absolute control, a high concentration of equity; without a large shareholder and a single shareholder holding less than $10 \%$ is considered highly dispersed equity; between the two is relative holding.

The composition of equity, that is, the number of shares held by different background shareholders. When the control of the enterprise can compete, the shareholders can and are willing to exercise effective control over the board of directors and the manager; in the case of non-competitive control, the controlling shareholder of the company will lock and weaken the supervision of the board of directors and managers.

In China, the shareholding structure usually refers to the shareholding ratio of the national shareholders, legal person shareholders and public shareholders of listed companies.

\subsection{Corporate Governance}

Corporate governance, also known as corporate governance structure, refers to the effective management and control of the company's owners and stakeholders, and accordingly handles the sum of various contractual relationships within and outside the company, divided into internal corporate governance and external corporate governance.

Internal corporate governance refers to the owner's supervision and balance mechanism for the operators, that is, through the shareholders' meeting, the board of directors, the board of supervisors and the management, reasonably define and configure the rights and responsibilities between the owners and the operators to ensure the shareholders, which is an institutional arrangement that maximizes benefits and prevents operators from deviating from the interests of their owners.

External corporate governance refers to the coordination of the interests of the company and its stakeholders through a set of internal and external systems to ensure the scientific and effective decision-making of the company and ultimately safeguard the interests of all aspects of the company.

\subsection{Relationship between Ownership Structure and Corporate Governance}

The shareholding structure is the basis of corporate governance. Corporate go- 
vernance is the specific operational form of ownership structure. Different ownership structures determine different organizational structures, determine different corporate governance structures, and ultimately determine business operations and operational performance.

In a company with a high concentration of equity, due to the lack of a property rights basis for the formation of power checks and balances, absolute shareholders can easily use the controlling position to completely control the company's board of directors and the board of supervisors. In corporate governance, it is easy to form "one big share" and "super control", resulting in Unbalanced and incomplete corporate governance has led to inefficient resource allocation.

In a company with highly dispersed equity, because there is no major shareholder, generally the ownership and management rights of the enterprise are completely separated. Many small shareholders have no enthusiasm and ability to participate in enterprise supervision and control, and it is easy to form internal control or operator-lead.

In a company with relatively scattered equity, since the control of the enterprise can compete, the shareholders can and are willing to exercise effective control over the board of directors and the manager, decentralization and balance can be effectively utilized.

Different types of shareholders also have a significant impact on business performance in corporate governance. Equity-distributed companies with social legal persons as their main shareholders perform better than corporate-controlled companies, and corporate-controlled companies perform better than state-owned companies [1].

Therefore, the appropriate equity and governance structure is the effective operation guarantee of the company. The relative ownership structure of several legal persons can play a role as a legal person shareholder, which can promote the perfect corporate governance structure; gradually reduce the company's equity concentration and prevent excessive concentration of equity due to appropriate methods. It is of great significance to reduce internal control and improve operational efficiency.

\section{Japan's Large Shipping Companies' Shareholding Structure and Corporate Governance}

\subsection{Current Status of Corporate Governance in Large Shipping Companies in Japan}

The maritime industry is a globally competitive industry. The three major shipping companies represented by merchant ship Mitsui MOL, Nippon Yusen NYK, and Kawasaki steamboat K-LINE have always been in the overall strengths such as capacity scale, income level, net interest rate and return on net assets. The forefront of the world, with strong international competitive advantage, has supported the status of Japan's maritime power and guaranteed the development of the Japanese national economy. 
The competitiveness of Japanese shipping companies is mainly reflected in four aspects:

First, the fleet is large and the structure is relatively reasonable.

The fleet size has long been in the top two in the world. In 2018, Japan had a capacity of 167.6 million deadweight tons, accounting for $13.6 \%$ of the world's total.

The second is the internal coordination mechanism of the consortium to improve the shipping industry chain.

Give full play to the consortium coordination mechanism, build a business cooperation upstream and downstream industry chain, mutual business, and realize the benefits sharing, risk sharing, and common development of the community of interests.

Promote diversification of equity, mutual business, cross-shareholding, solid board of directors, improve corporate governance, guarantee cargo transportation, enhance the sustainable development capacity of shipping companies and the competitiveness of the international market.

The third is the intensification strategy to cultivate the "hundred-year-old shop" of the shipping industry.

After the Second World War, Japan's “intensity intensive” policy, cultivating super-marine enterprises, enhancing the competitiveness of the international shipping market, and forming a unique competitive advantage in LNG, oil transportation and dry bulk cargo transportation, ensuring the domestic cargo carrying rights, and seized Contract for shipping in emerging countries.

Fourth, the main bank held shares for a long time and established a stable relationship between banks and enterprises.

Japanese shipping companies maintain close relationship with the main banks within their consortiums. The top ten shareholders are almost all financial institutions, ensuring low-cost financing channels, coupled with financial liberalization, financial holding bans, Mitsubishi UFJ Financial Group, Mizuho Financial Group, as shown in Figure 1. The three major financial institutions, such as Sumitomo Mitsui Financial Group, are a four-in-one mixed operation of banking, investment, trust and insurance, providing strong financial backing, showing in Figures 2-5.

The strong competitiveness of Japanese shipping companies is benefited from the strong support of the Japanese government and the Japanese special financial group system. It is also attributed to its own corporate governance. Through equity diversification, it has mutual stock ownership and strategic cooperation with shippers to build upstream and downstream industrial chains. The formation of interest sharing and risk-sharing interests' community can be used as reference and enlightenment for China's large shipping companies to optimize their shareholding structure and improve corporate governance.

\subsection{Characteristics of the Shareholding Structure of Japanese Large Shipping Companies}

After the Second World War, the Japanese economy was democratized, the 


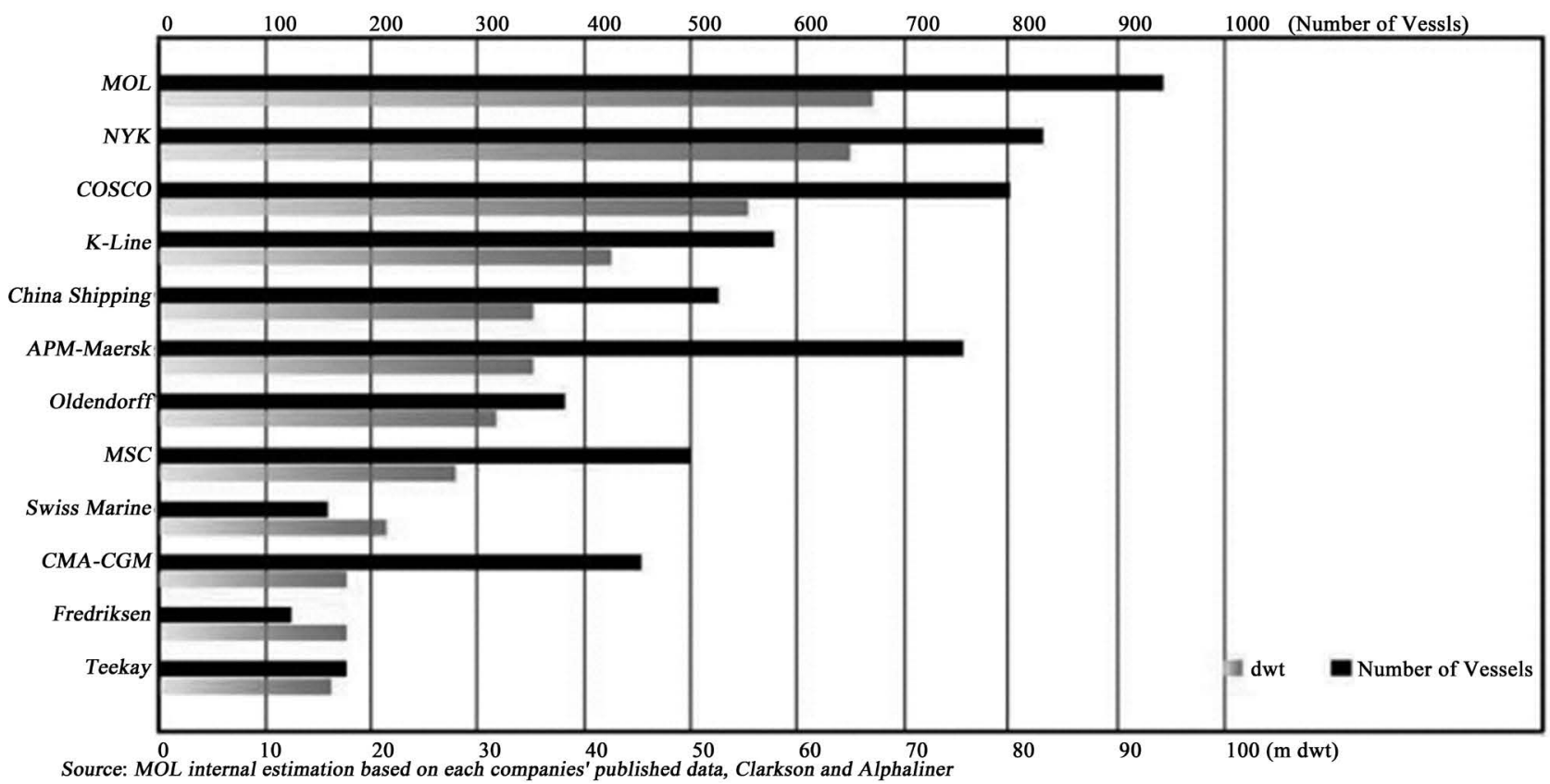

Figure 1. Comparison of the capacity of the world's top ten shipping companies in 2017.

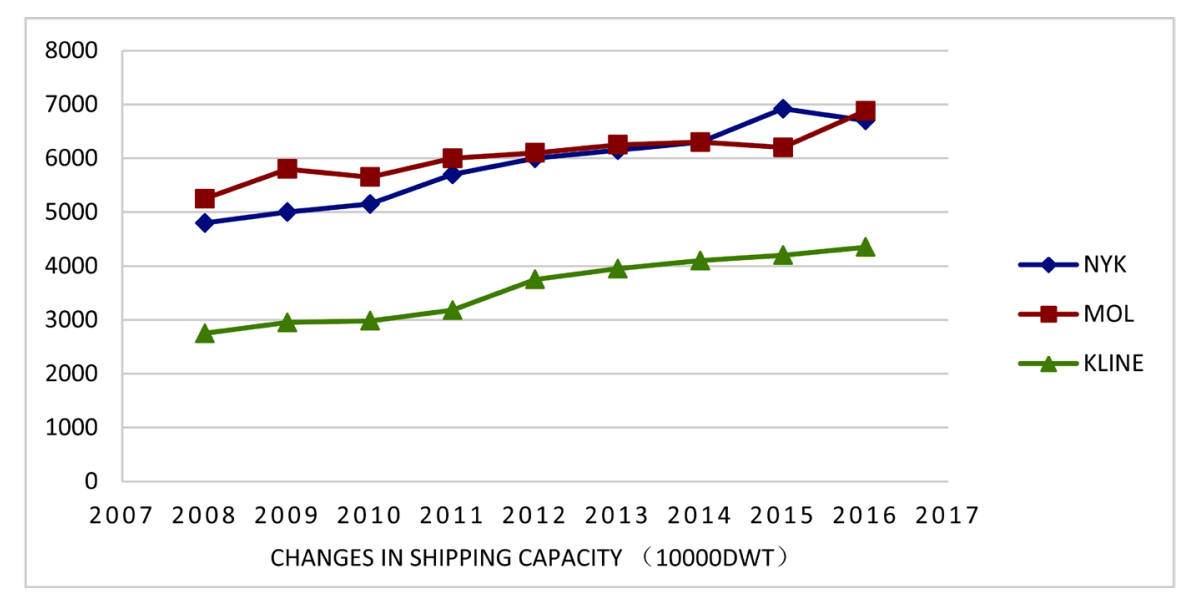

Figure 2. Changes in shipping capacity of Japan's three major shipping groups (10 thousand DWT).

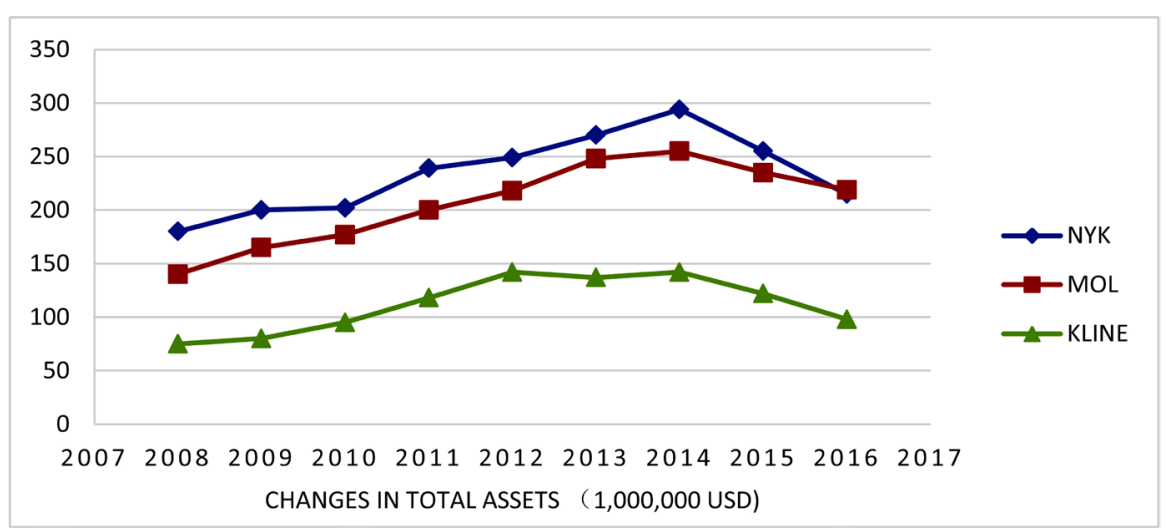

Figure 3. Changes in total assets of Japan's three major shipping groups (hundred million USD). 


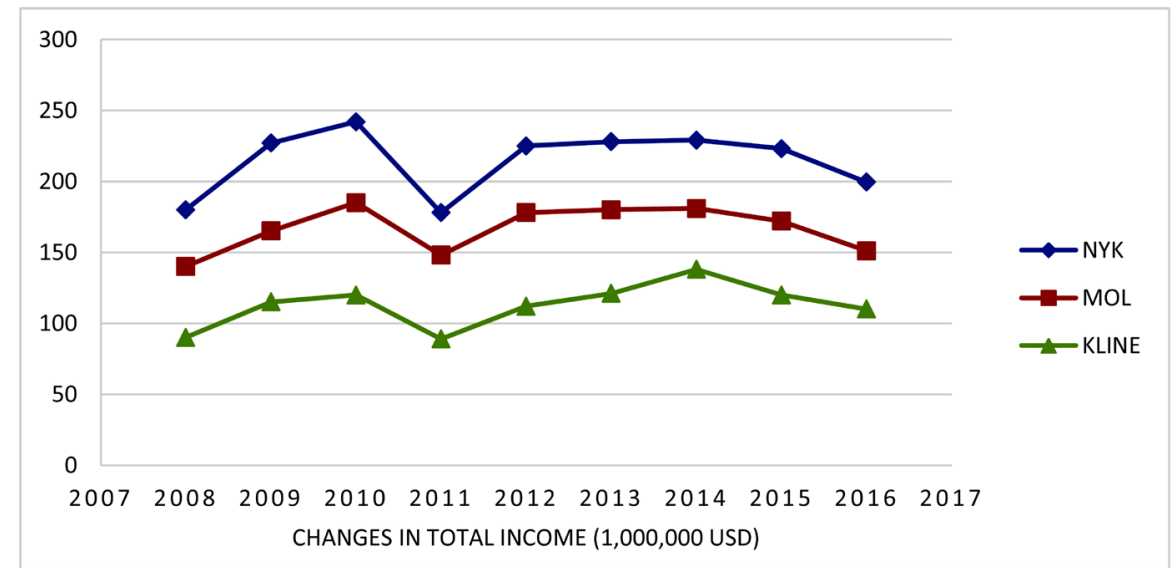

Figure 4. Japan's three major shipping groups (hundred million USD).

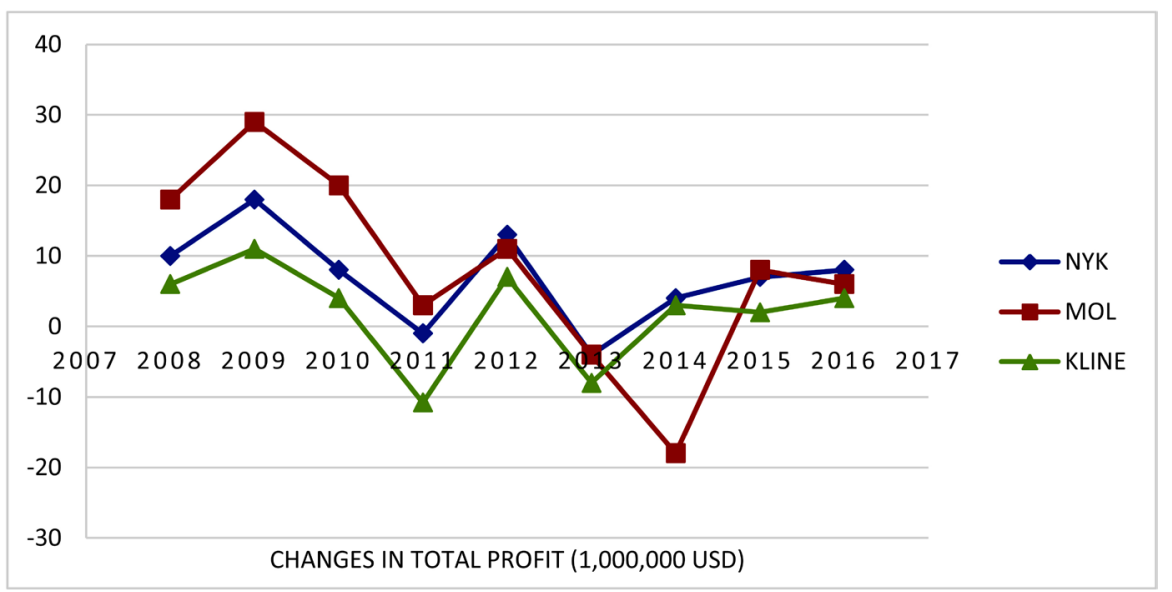

Figure 5. Changes in total profit of Japan's three major shipping groups (hundred million USD). Resource: Annual report of the companies.

chaebol was disbanded, the shareholding structure was diversified, and each other held shares, forming a phenomenon of corporate equity legalization [2].

Among several enterprises, one enterprise is the shareholder of all or part of other enterprises, and these companies (or their subsidiaries, grandchildren) hold their shares [3]. The mutual ownership of legal persons has weakened ownership to a certain extent, and the status and role of the operators have been highlighted [4].

The ownership structure of mutual shareholding enterprises is stable, ensuring the long-term stability and stability of the business management policies, and enhancing the ability of enterprises to cope with the crisis. It will greatly promote the rapid improvement of operating efficiency and adapt to the fiercely competitive market environment, and directly promote the rapid development of the Japanese economy.

With the transfer of mutual shareholdings, the shareholding structure of Japan's three major shipping companies is increasingly fragmented. At present, the top ten shareholders hold a total of no more than $40 \%$ of the shares, mainly financial institutions and business corporations, showing in Tables 1-3. 
Among them, Japan Trust Service Trust Bank and Japan MasterCard Trust Bank are the two major shareholders, holding nearly $20 \%$ of the shares. The former is owned by Sumitomo Trust Bank, Sona Bank and Mitsui Trust, each holding 33\%, which is the core financial institution of Mitsui Foundation; The latter is $46.5 \%$ owned by Mitsubishi UFJ Trust Bank Co., Ltd. and 33.5\% owned by Japan Life Insurance Co., Ltd., which is the core financial institution of Mitsubishi Consortium [5] [6] [7].

Japan's Mizuho Corporate Bank, Japan Asset Management Service Trust Bank, Table 1. NYK List of major shareholders (2018 Fiscal year).

\begin{tabular}{lcc}
\hline \multicolumn{1}{c}{ Majot Shareholders } & $\begin{array}{c}\text { Number of shares } \\
\text { held (thousands) }\end{array}$ & Ratio (\%) \\
\hline The Master Trust Bank of Japan, Ltd. (Trust Accounts) & $11,692,100$ & 7.17 \\
Japan Trustee Services Bank, Ltd. (Trust Accounts) & $11,357,900$ & 5.97 \\
MINAMI AOYAMA REAL ESTATE CO., Ltd. & $8,247,800$ & 2.52 \\
Mitsubishi Heavy Industries, Ltd. & $4,103,831$ & 2.11 \\
Meiji Yasuda Life Insurance Company & $3,447,326$ & 1.90 \\
Japan Trustee Services Bank, Ltd. (Trust Accounts 5) & $3,105,600$ \\
Tokio Marine and Nichido Fire Insurance Co., Ltd. & $2,894,578$ \\
Japan Trustee Services Bank, Ltd. (Trust Accounts 9) & $2,801,500$ \\
JP MORGAN CHASE BANK 385151 & $2,478,550$ & 1.72 \\
STATE STREET BANK WEST CLIENT-TREATY 505234 & $2,372,412$ & 1.52 \\
TOTAL & $52,501,597$ & 32.20 \\
\hline
\end{tabular}

Resource: https://www.nyk.com/english/ir/library/result/2018/_icsFiles/afieldfile/2019/05/22/190426FB1E.pdf.

Table 2. MOL List of major shareholders (2018 Fiscal year).

\begin{tabular}{lcc}
\hline \multicolumn{1}{c}{ Majot Shareholders } & $\begin{array}{c}\text { Number of shares } \\
\text { held (thousands) }\end{array}$ & $\begin{array}{c}\text { Ratio } \\
(\%)\end{array}$ \\
\hline The Master Trust Bank of Japan, Ltd. (Trust Account) & 8155 & 6.82 \\
Japan Trustee Services Bank, Ltd. (Trust Account) & 7090 & 5.93 \\
BNYMSANV AS AGENT/CLIENTS LUX UCITS NON TREATY 1 & 4868 & 2.92 \\
Japan Trustee Services Bank, Ltd. (Trust Account 9) & 3490 \\
Mitsui Sumitomo Insurance Co., Ltd. & 3016 & 2.52 \\
Sumitomo Mitsui Banking Corporation & 3000 \\
Japan Trustee Services Bank, Ltd. (Trust Account 5) & 2210 \\
HSBC BANK PLC A/C CLIENTS 1 & 2129 \\
STATE STREET LONDON CARE OF STATE STREET BANK AND \\
TRUST, BOSTON SSBTC A/C UK LONDON BRANCH CLIENTS-UK \\
STATE STREET BANK WEST CLIENT-TREATY 505,234
\end{tabular}

Resource: https://www.mol.co.jp/en/ir/stock/b-information/index.html. 
Table 3. KLINEList of major shareholders (2018 Fiscal year).

\begin{tabular}{ccc}
\hline Majot Shareholders & $\begin{array}{c}\text { Number of shares } \\
\text { held (thousands) }\end{array}$ & Ratio (\%) \\
\hline SMP PARTNERS (CAYMAN) LIMITED & 15,297 & 16.31 \\
GOLDMAN SACHS INTERNATIONAL & 9989 & 10.65 \\
MLI FOR CLIENT GENERAL OMNI NON COLLATERAL & 5151 & 5.49 \\
NON TREATY-PB & 3392 & 3.61 \\
Trust \& Custody Services Bank, Ltd. & 3119 & 3.32 \\
ECM MF & 3067 & 3.27 \\
The Master Trust Bank of Japan, Ltd. (trust account) & 2910 & 3.10 \\
IMABARI SHIPBUILDING Co., Ltd. & 2817 & 3.00 \\
JFE Steel Corporation & 2100 & 2.24 \\
J.P.MORGAN SECURITIES PLC FOR AND ON BEHALF OF & 1910 & 2.03 \\
ITS CLIENTS JPMSP RE CLIENT ASSETS-SEGR ACCT & 53.02 \\
Sompo Japan Nipponkoa Insurance Inc. & 49,752 & 3 \\
TOTAL &
\end{tabular}

Resource: https://www.kline.co.jp/en/ir/stock/info.html.

Nomura Trust and Japanese insurance companies as joint shareholders reflect Japan's special main banking system, that is, the consortium holds the shares of the industrial company through the bank and the financial control platform; Mutual shareholding relationship, maintaining an important link in the business exchanges of member companies.

As the second largest steel company in the world, Japan Steel Engineering Holding Co., Ltd. has strong demand for transportation of bulk raw materials such as iron ore and coal. It directly holds nearly $3 \%$ of the shares of Nippon Yusen and Kawasaki steamships, reflecting the large-scale shipping company. Shares, participate in the daily operations of shipping companies, and seek stable transportation security.

\subsection{The Ownership Structure of Japanese Maritime Enterprises and the Enlightenment}

1) The shareholding structure is the property rights basis of the corporate governance mechanism.

The formation and evolution of the equity structure of Japanese shipping companies are the results of multiple factors, including historical conditions for their generation and development, including social history, politics, law, economic development, and international external environment. Chinese shipping companies adjust their equity. Structure, improve corporate governance, should carefully analyze the different stages of economic development, and fully consider various factors, and steadily advance it [8].

2) A diversified shareholding structure can play an active role.

The diversified shareholding structure of shipping companies and the mutual 
shareholding among domestic enterprises have played an active role in promoting the independence of the Japanese national economy, promoting the development of the national economy, and enhancing the international competitiveness of enterprises. Chinese enterprises have developed a transnational economy and implemented "going out". Strategy, participating in economic globalization has played a good demonstration effect [9].

3) The positive role of corporate shareholders is conducive to improving corporate governance.

Through the incentive and restraint mechanism, legal person shareholders exert pressure on the operators and strengthen the supervision function. In addition, domestic legal person shareholders pay more attention to long-term interests than foreign legal person shareholders. Therefore, Chinese shipping companies should pay more attention to legal person shareholders and strive to play the supervisory mechanism of institutional shareholders and to achieve greater results in improving corporate governance.

4) Introducing strategic investors is conducive to enhancing the company's competitiveness.

Large-scale financial institutions and large-scale enterprises that introduce energy, resources and trade enterprises, especially the "going out" strategy, participate in state-owned shipping enterprises, establish stable cooperative relations, build equity groups with equity diversification and long-term transportation contracts, and build industrial chains. Competitive advantages, for Chinese shipping companies to enhance their competitive advantage and improve business performance, will play a good role in promoting Chinese enterprises to "go global" and to participate in the "Belt and Road" construction, and enhance their competitiveness.

\section{Conclusion: China's Large Shipping Enterprise Equity Structure and Corporate Governance Optimization Suggestions}

\subsection{China's Large Shipping Companies' Integration and Background of Restructuring}

The shipping industry is a strategic industry that is related to the national economy. As early as 2006, the Chinese government listed the shipping industry as one of the seven industries that must maintain absolute control over the state-owned economy.

Since 2015, the state has initiated the integration of shipping companies. On December 11, COSCO Group and China Maritime Reorganization Plan were approved by the State Council [10]. On December 29, the State Council approved the integration of Sinotrans Changhang Group into the China Merchants Group [11]. On February 18, 2016, the newly formed China Ocean Shipping Group Co., Ltd. was officially listed for operation.

On December $28^{\text {th }} 2015$, after the approval from the State Council, China 
Merchants Group and Sinotrans Changhang Group implemented a strategic reorganization. Sinotrans Changhang Group was integrated into China Merchants Group as a wholly-owned subsidiary by way of free transfer.

Merger and reorganization are important means to optimize industrial structure and enhance the competitiveness of enterprises. They can rapidly enhance the competitiveness of enterprises, form economies of scale, accelerate the optimization of industrial structure, realize the global allocation of resources, and finally achieve "four concentrations", that is, promote the relationship between state-owned capital. The important industries and key areas of national security and the lifeline of the national economy are concentrated, and the industries with competitive advantages of the state-owned economy and the areas where the leading industries may be formed in the future are concentrated, and concentrated to large enterprises and large enterprise groups with strong international competitiveness, concentrated to the main industry of the corporation [12].

\subsection{Shareholding Structure Optimization Proposal}

As the scale of the enterprise continues to expand, the degree of professionalism of the enterprise continues to increase. The large state-owned shipping enterprises established after the integration and reorganization should actively learn from the experience of Japanese shipping companies in focusing on internal governance and strengthening the construction of the industrial chain. On the one hand, insist on perfecting large customer-strategy to strengthen business model innovation, improve the industrial chain and value chain, jointly stabilize the volatility of the maritime market, and maintain healthy development.

On the other hand, gradually reducing the company's equity concentration, from the original state-owned sole proprietorship to several state-owned shareholders to jointly contribute to the transformation together with appropriate introduction of non-state-owned shareholders can format a diversified ownership structure, so that corporate governance and industrial structure is more scientific. It will also protect the company's shareholders on the behavioral norms, more effective internal constraints and more efficient and flexible operation. Once the corporate governance structure is improved, it is accelerated by the benign endogenous driving force for the independent development of the enterprise.

\subsection{Corporate Governance Optimization Advice}

Stablishing a modern enterprise system, improving corporate governance structure, and improving business performance have always been the focus of state-owned enterprise reform. Since 2004, the State-Owned Assets Supervision and Administration Commission of the State Council has standardized the construction of the board of directors, granted the decision-making power of the board of directors of the central enterprises, appointed external directors, and initially established the corporate governance structure of the board of directors, 
the management of the management, and the supervision of the board of supervisors [13]. In order to enhance the independence of the board of directors, a new round of state-owned enterprise reform has proposed a solution in a targeted manner- "implementing and maintaining the board of directors to exercise major decisions, selecting people and employing people, and paying salaries according to law". The law does not authorize any government departments or agencies to intervention [14].

After the intensive integration and reorganization of China's large shipping companies, the scale of the company and the specialization of operations will be upgraded. The corporate governance will gradually be transformed from the original shareholders to the board of directors, centering on the sound functions of the board of directors, playing a role, and improving the corporate governance mechanism.

The first is to increase capital and expand shares, improve the shareholding structure, and actively introduce qualified corporate investors, especially highquality strategic investors. It is necessary to actively introduce the participation of upstream and downstream enterprises in the industrial chain, strengthen the construction of the industrial chain, change from single structure to diversification, optimize the composition of the board of directors, introduce the upstream and downstream industry entities, introduce advanced management concepts and risk management techniques, and improve corporate governance and management level of shipping companies.

The second is to improve the organizational structure of the board of directors, and to establish and improve corresponding professional committees, such as risk management committees, nomination and remuneration committees, advanced technical committees, in accordance with the characteristics of shipping companies and future development trends, to assist the board of directors in handling relevant professional work and to provide professional advice. Promote the transformation of enterprises from maritime carriers to global logistics operators, from multinational operations to multinational corporations, and finally realize the transformation of economic benefits from big ups and downs to steady and sustainable development.

The third is to optimize the composition of the board of directors, focus on promoting the construction of the board of directors according to the adjustment of the shareholding structure, increase the number and proportion of the corresponding equity directors, let the equity directors truly perform their duties, implement the board of directors, establish equal rights and responsibilities, coordinate coordination, and effectively The decision-making implementation supervision mechanism of checks and balances truly solves the agency relationship between investors and operators.

Fourth, we must establish a standardized information reporting system, clarify the specific report content, time, frequency to effectively solve the problem of information asymmetry between the board of directors and the management, 
and avoid internal control.

Fifth, we must actively promote the market-based employment system, adhere to institutional innovation, management innovation and business model innovation, and achieve standardized corporate governance, in order to form a benign endogenous driving force for enterprise development.

\section{Conflicts of Interest}

The authors declare no conflicts of interest regarding the publication of this paper.

\section{References}

[1] Shi, D.H. (2000) Equity Structure, Corporate Governance and Performance. World Economy, No. 12, 37.

[2] Luo, J.H. (2006) Japanese Corporate Governance Structure and Its Enlightenment to China. Corporate Economy, No. 1, 95.

[3] Gao, W. (2008) A Review of the Research on Mutual Shareholding in Japan. Modern Japanese Economy, No. 1, 39.

[4] Li, Y.J. (2014) Analysis of the Shareholding Structure of Japanese Listed Companies. China Steel Industry, No. 7, 14.

[5] https://www.nyk.com/english/ir/library/result/2018/_icsFiles/afieldfile/2019/05/22/ 190426FB1E.pdf.

[6] https://www.mol.co.jp/en/ir/stock/b-information/index.html.

[7] https://www.kline.co.jp/en/ir/stock/info.html.

[8] Li, B. (2008) The Evolution of Japan's Shareholding Structure and Its Impact on Corporate Governance. Japanese Journal, 3, 65.

[9] Chen, Q.W. (2009) Briefly on the Experience and Lessons of Japan's Mutual Shareholding System. Economic and Social Development, No. 10, 51.

[10] Xinhuanet. COSCO Zhonghai Restructuring Plan Was Approved. http://news.xinhuanet.com/politics/2015-12/15/c_128530790.htm

[11] State-Owned Assets Supervision and Administration Commission of the State Council. China Merchants Group Co., Ltd. and Sinotrans Changhang Group Co., Ltd. Implemented Strategic Restructuring. http://www.sasac.gov.cn/n2588035/n2641579/n2641660/c3753582/content.html

[12] Li, J. (2015) The Big Restructuring of Central Enterprise Reform Will Begin-Thinking about the Reform Mode and Approach of Central Enterprise Restructuring. China Ocean Shipping, No. 1, 20.

[13] Liu, Z.Q. (2015) The Board of Directors Cannot Be Used as a "Vase". People's Daily, 2015-12-14 (017).

[14] Xinhuanet. Guiding Opinions of the Central Committee of the Communist Party of China and the State Council on Deepening the Reform of State-Owned Enterprises. http://www.scio.gov.cn/32344/32345/33969/34577/xgzc34583/Document/1478256/1 478256.htm 